\title{
An Exploratory Study of Women Entrepreneurs in Malaysia: Motivation and Problems
}

\author{
Syed Shah Alam (Corresponding author) \\ Faculty of Economics and Management \\ Universiti Kebangsaan Malaysia (National University of Malaysia) \\ E-mail: shahalam@ukm.my \\ Zizah Che Senik \\ Faculty of Economics and Management \\ Universiti Kebangsaan Malaysia (National University of Malaysia) \\ E-mail: zizahcs@ukm.my
}

Fauzi Mohd Jani

Center for Entrepreneurship and SMEs Development (UKM-CESMED)

Universiti Kebangsaan Malaysia (National University of Malaysia)

Received: Sep. 12, 2012

doi:10.5296/jmr.v4i4.2377
Accepted: Sep. 25, 2012 Published: October 1, 2012

URL: http://dx.doi.org/10.5296/jmr.v4i4.2377

\begin{abstract}
Entrepreneurial activity relating to women entrepreneurs has been the interest of many researchers, as they have become the main contributors to today's economy. However, not much is known about what motivates and hinders 'womenpreneurs' in their entrepreneurial process. This paper examines the motivational factors and barriers of 194 Malaysian womenpreneurs who were randomly selected from a list of Federation of Women Entrepreneur Associations in Malaysia. The research design in this study focused on the primary data collected using a self administered questionnaire that was distributed through mail survey. The instruments assessed relevant areas, such as demographic and business information, motivations, entrepreneurial characteristics, and business problems. Result of
\end{abstract}




\section{Macrothink}

Journal of Management Research ISSN 1941-899X 2012, Vol. 4, No. 4

the survey shows that women entrepreneurs do have problems when they enter into the business. The implications of this study are discussed along with some recommendations.

Keywords: Women, Entrepreneurs, Motivations, Problems, Malaysia. 


\section{Introduction}

According to Pages (2005) women entrepreneurs are becoming more important players in the entrepreneurial landscape. Although the number is still small as compared to businesses owned by men, this is encouraging as it shows that women no longer adhere to the stereotype that only men can be wage earners in the family. Although there are numerous obligations including take care of family by women, but still it is admirable that women can find success through their own businesses.

Though there have been limitations, obstacles and roadblocks faced by these women in the past, society have begun to accept that women entrepreneurs do contribute greatly to a country's economy. As such, it is no longer unexpected to see women heading their own companies and being successful at the same time. The general mindset has changed so much so that women who juggle family with careers are looked upon as capable and independent women who have the best of both worlds. In addition to that, it is no longer strange to have business dealings with a female.

There more and more women are enrolled in the higher education then men but still women are less than the men entrepreneurial jobs in Malaysia. Nevertheless, it is still lower than that in many developed countries such as 51\% of women in Singapore, 56\% in USA and 53\% in UK (Ministry of Labour Singapore). In Malaysia, of 10.8 million workforces, only 37\% are women (cited by Emily Tan, 2009). More women are enrolled in higher education than men, and many of educators (school teachers) involved women comparing to men. However, in regard to entrepreneurial jobs, women are less than the men. According to Rozy (2009) women make $50 \%$ total population, but only $15 \%$ of the women own business enterprises in Malaysia. Although there is no data on the number of women involved in small business, but in the last few decades women participation in small businesses increased tremendously. Indeed, there are growing women entrepreneurs in Malaysia (Teoh and Chong, 2008), and they play major roles in promoting the development of Malaysia economic, as well as help providing job opportunities (Isa and Jusoff, 2009).

Most of the researches on entrepreneurs are mainly focused on the men entrepreneurs than women entrepreneurs. Some of the literature concerning this subject often focus either on the reasons that women choose to become entrepreneurs (Buttner and Moore, 1999; Lee, 1997; Sarri and Trihopoulou, 2005) or on the barriers that these women face while attempting to start up a business (Menzies, Diochon and Gasse, 2004; Brindley, 2005). According to Hisrich and Öztürk (1999), although there are some researches on women entrepreneurs, they have been conducted extensively in developed countries, and little has been done on women entrepreneurs in developing economies, such as Malaysia (Alam et al., 2011). Although researchers such as (Isa and Jusoff, 2009) and Ndubisi and Kahraman (2005) have contributed to empirical evidence on Malaysian women entrepreneurs, but their focus were on women and ICT and women and opportunities, respectively. This study will be one of the exploratory in nature mainly focuses on the entrepreneurial future plan, problems entering on business and the motivation for entering entrepreneurial jobs women in Malaysia. 


\section{Literature Review}

\subsection{Motivation of women to enter into business}

Most of the past researchers have examined the reasons entrepreneurs initiate ventures (Birley and Westhead 1994; Cooper and Dunkelberg 1981; Denison and Alexander 1986; Dubini 1988; Scheinberg and MacMillan 1988; Shane, Kolvereid, and Westhead 1991; Shapero 1975). In particular to women entrepreneurs, who are responsible for both work and family (Buttner and Moore, 1997), often leave the corporate world to become entrepreneurs (by starting their own businesses) to provide additional flexibility and life balance in managing their traditional responsibilities as wife and primary caretaker of children (Nguyen, 2005). Helms (1997) studied on US workforce and explains that women often start their own business for "three types of personal gains: personal freedom, security, and/or satisfaction". Researcher describe in the research "freedom seekers" as those who are dissatisfied with their employment due to pay inequities or discrimination and desire the freedom to choose their preferred type of work (i.e. hours of work, environment, and people they work with). The work flexibility provided by entrepreneurship is appealing for women in terms of location, often working at home or close to home, and the hours of work. "Security seekers" are those who have been prompted to become an entrepreneur due to some personal misfortune, such as layoff, downsizing, divorce, death or retirement of their spouse. These "security seekers" start a business to improve or maintain their family social or economic status. The "satisfaction seekers" are housewives who do not have any previous work skills or experience but want to prove to others or themselves that they can be productive and useful in society.

Hisrich and Brush (1985) studied on women's entrepreneurial motivation and examine the reasons for women to start their businesses. This study reveals that "push" factors including frustration and boredom in their previous jobs and "pull" factors such as autonomy are the main reasons for starting new business. Another research by Stokes, Riger, and Sullivan (1995) found that women see work environments in large organizations as significantly more hostile and that this perception was related to women's turnover intentions. Thus, "push" factors may be a more important influence for women than for men. Additional evidence of Larwood and Gattiker's (1989) study on career paths of men and women suggesting that, women's careers cannot be well understood by studying the patterns of men. So women start their own business rather than working in the organizations.

Scott (1986) study reported that women entrepreneurs wanted to be their own boss, wanted the challenge, or wanted to make more money. Another studied on 20 women entrepreneurs by Schwartz (1979) found that women were started business mainly the need to achieve, a desire to be independent, the need for job satisfaction, and or was an economic necessity. Chaganti (1986) study support and extended the findings of the study of Hisrich and Brush (1985) and found that job frustration, service needs, having an attractive business idea, a desire to be their own boss, a desire to make it on their own and build something of their own, and monetary success are some reasons for women setting-up businesses. 


\subsection{Barriers of women starting or owning business}

There are numerous barriers which are facing women entrepreneurs when they are starting a new business. Winn (2005) reported that two biggest hurdles (funding and family support) women face in starting and running a company. Gundry et al., (2002) found that lack of access to capital has been a primary obstacle for women entrepreneurs. Helmi's (1997) study supported and stated that, financial aspects of venture start-up management are the biggest obstacles for women. This is including start-up financing and credit, cash flow management in the early operation and financial planning. Women in business funding mainly collecting through family loans, personal savings, credit cards, and home equity loans (Gundry et al., 2002). Van der Merwe (2003) identifies major barriers for women entrepreneurs are, lack of access to financial resources, lack of support, negative prevailing socio-cultural attitudes, gender discrimination, personal difficulties, lack of basic life skills such as self-confidence, self-motivation and communication skills.

Other barriers for women entrepreneurs are limited education and vocational training in developing countries in particular (Chandralekha et al, 1995), no collateral and no or a poor credit history, no business track record, lack of legal status (Brown, 1997), family commitments of married women (Hamilton, 1993; Stoner et al, 1990), and female entrepreneurs avoiding the male-dominated business sectors (Erwee, 1987; Adams et al, 1999).

Family structure is playing another dominant role persisting women from entrepreneurial society. Women in transition economies suffered from traditional perceptions about women's role in society, and these attitudes persist (Erdem, 2002;

Hovet, 2004). Still the women careers depend on the decision of their spouses rather than the other way around (Fernandez, 1981).

\section{Research Methodology}

To investigate the women entrepreneurs in Malaysia, the following research methodology was employed in this study:

\subsection{Data collection instrument}

Based on similar studies in the literature, a questionnaire was developed for data collection for this study. A survey instrument was formulated to obtain feedback from the women entrepreneurs, assessing their background, their motivation, and the barriers they faced for starting new business. Study questionnaire included four sections. In the first section, demographic information about the entrepreneurs and their businesses was collected. Section 2 included questions in regards to motivational factors, attitudes about entrepreneurship and entrepreneurs, and attributes needed to be an entrepreneur. Third section included statements about the problems faced by the entrepreneurs. These two sections were measured using a Likert scale ranging from 1 (strongly disagree) to 6 (strongly agree). Most of these questions were adopted from Western studies (Winn, 2005; Turan \& Kara, 2007; Nguyen, 2005). Finally in the fourth section, entrepreneurs were asked to indicate the importance of certain 
factors for their future plans. Since most of the scale items were extracted from Western sources, they were adapted and modified to the Malaysian environment.

After the questions were generated from the entrepreneur's interviews, it was pre-tested on a sample of 20 respondents. By administering the pre-test, we could ensure that the attributes measured in the study reflected actual interactions and expectation from the entrepreneurs when starting and involving their business. It was decided to keep all items in the research so as to have contributions on a wider scale to see if these items indeed measured the same constructs form the entrepreneur's point-of-view.

\subsection{Data collection and sampling}

The questionnaire was developed in English using the available scales in the literature and then translated into Bahasa Malaysia and administered. To ensure the accuracy of the translation, a back translation was completed to check for any inconsistencies or possible translation errors. The questionnaire was also administered to a group of Malaysian entrepreneurs to pilot test the questionnaire for clarity, comprehension, and consistency, and the appropriateness of items on the questionnaire.

The data for the study were collected from Malaysian entrepreneurs in two states in southern region of Malaysia. The sample for this study was composed of 194 entrepreneurs Malaysia. Women entrepreneurs of the SMEs of each organization were the respondents. Simple random sample method was used to distribute the questionnaire using trained research assistants. A total of 250 questionnaires were distributed and 199 returned (79.6 percent response rate). Due to missing values for at least two sections of the responses 5 samples were discarded from this research and finally 194 samples were then processed and analyzed.

\subsection{Statistical tools}

Bivariate frequency distribution of the respondents, according to age, tenure, gender and length of services was presented. Descriptive statistics were computed to examine different levels of satisfaction with each of their primary tasks. Data were collected on demographic variables are processed and reported in percentage through the descriptive analysis. Descriptive analysis refers to the transformation to describe a set of factors that will make them easy to understand and interpret (Sekaran, 2000; Zikmund, 2000).

\section{Analysis and Results}

\subsection{Demographic profile of respondents}

Table 1 shows the age of the women entrepreneurs. In consistent with the research of Turan and Kara (2007) this research also found that over half (53.6\%) of the respondents age were between 25-40years. Study by Hisrich and Peters (1996) and Cetindamar (2005) also confirmed these same characteristics, which providing further support to the representativeness of our sample. In addition to that, most of the respondents were married (75.3\%) while only $24.7 \%$ of the respondents are single. Furthermore, the table also shows that the most number of respondents are Malays (46.4\%), followed by Indians (25.8\%) and 
then finally Chinese (23.7\%), as Malays make up 60 per cent of the total Malaysian population.

Table 1. Distribution of Demographic Characteristics

\begin{tabular}{|c|c|c|c|}
\hline \multicolumn{2}{|c|}{ Demographic Characteristics } & \multirow{2}{*}{$\begin{array}{c}\text { Frequency } \\
\boldsymbol{f} \\
10\end{array}$} & \multirow{2}{*}{$\begin{array}{c}\begin{array}{c}\text { Percentage } \\
\text { \% }\end{array} \\
5.2\end{array}$} \\
\hline Age & Below 25 & & \\
\hline & $25-30$ & 44 & 22.7 \\
\hline & $31-40$ & 60 & 30.9 \\
\hline & $41-50$ & 50 & 25.8 \\
\hline & $51-60$ & 12 & 6.2 \\
\hline & above 60 & 18 & 9.3 \\
\hline & Total & 194 & 100 \\
\hline \multirow[t]{3}{*}{ Marital Status } & Married & 146 & 75.3 \\
\hline & Single & 48 & 24.7 \\
\hline & Total & 194 & 100 \\
\hline \multirow[t]{5}{*}{ Race } & Malay & 50 & 46.4 \\
\hline & Chinese & 46 & 23.7 \\
\hline & Indian & 50 & 25.8 \\
\hline & Others & 8 & 4.1 \\
\hline & Total & 194 & 100 \\
\hline \multirow{7}{*}{$\begin{array}{l}\text { Highest Level of } \\
\text { Education }\end{array}$} & SPM/ O-Level & 59 & 30.4 \\
\hline & STPM/ A-Level & 32 & 16.5 \\
\hline & Diploma & 64 & 33.0 \\
\hline & Undergraduate & 36 & 18.6 \\
\hline & Master & 3 & 1.5 \\
\hline & $\mathrm{PhD}$ & 0 & 0 \\
\hline & Total & 194 & 100 \\
\hline \multirow[t]{6}{*}{ Religion } & Muslim & 88 & 45.3 \\
\hline & Buddhist & 18 & 9.3 \\
\hline & Hindu & 30 & 15.5 \\
\hline & Christian & 36 & 18.6 \\
\hline & Others & 22 & 11.3 \\
\hline & Total & 194 & 100 \\
\hline \multirow[t]{5}{*}{ Position in Family } & First-born & 58 & 29.9 \\
\hline & Second-born & 66 & 34 \\
\hline & Youngest & 42 & 21.6 \\
\hline & Others & 28 & 14.4 \\
\hline & Total & 194 & 100 \\
\hline \multirow{3}{*}{$\begin{array}{l}\text { Family history of } \\
\text { self-employment }\end{array}$} & Yes & 119 & 61.3 \\
\hline & No & 75 & 38.7 \\
\hline & Total & 194 & 100 \\
\hline
\end{tabular}


As expected over seventy percent of the women entrepreneurs had less then undergraduate degree. This finding is consistent with the study of Turan and Kara (2007). Majority of the women entrepreneurs were Muslim and interestingly, the women entrepreneurs who were approached to answer the questionnaire were mainly the second-born in the family $-34 \%$ of the overall respondents. Over half of the respondents had a family history of self-employment, of which was consistent with the existing entrepreneurship literature (Turan \& Kara, 2007).

\subsection{Nature of the Venture}

This section highlights some demographics of the women entrepreneurs that are pertinent to the entrepreneurs' business (Table 2). These characteristics include past working experience, source of personal start-up and reasons for entering self-employment. The distribution of the cumulative response based on the questionnaires is as follows:

Table 2. Nature of the Venture

\begin{tabular}{|c|c|c|c|}
\hline \multicolumn{2}{|c|}{ Demographic Characteristics } & \multirow{2}{*}{$\begin{array}{c}\text { Frequency } \\
\boldsymbol{f} \\
160\end{array}$} & \multirow{2}{*}{$\begin{array}{c}\begin{array}{c}\text { Percentage } \\
\text { \% }\end{array} \\
82.5\end{array}$} \\
\hline Past Working Experience & Yes & & \\
\hline & No & 34 & 17.5 \\
\hline & Total & 194 & 100 \\
\hline \multirow{3}{*}{$\begin{array}{l}\text { Source of Personal } \\
\text { Start-Up }\end{array}$} & Inheritance & 16 & 8.2 \\
\hline & Self-start & 188 & 91.8 \\
\hline & Total & 97 & 100 \\
\hline \multirow[t]{5}{*}{ Source of Financing } & Family & 56 & 28.9 \\
\hline & Friends & 4 & 2.1 \\
\hline & Loan from Bank & 134 & 69.1 \\
\hline & Others & - & - \\
\hline & Total & 194 & 100 \\
\hline Years of & Less than 1 year & 8 & 4.1 \\
\hline \multirow[t]{5}{*}{ Self-Employment } & 1 to 2 years & 32 & 16.5 \\
\hline & 2 to 5 years & 66 & 34.0 \\
\hline & 5 to 10 years & 62 & 32.0 \\
\hline & More than 10 years & 26 & 13.4 \\
\hline & Total & 194 & 100 \\
\hline
\end{tabular}

A whopping $82.5 \%$ of the respondents have previous working experience before starting up their own business whereas only $17.5 \%$ of them state that their current business is their first job. Most of the respondents (91.8\%) started their business on their own while the remaining $8.2 \%$ inherited their current business from close family and relatives. Taking a loan from the bank seems to be the most popular source of funding, with $69.1 \%$ of the respondents stating that that is what they did to finance their business. Only $28.9 \%$ of them received loans from family members while $2.1 \%$ borrowed from friends. A vast majority of respondents (34\%) 


\section{Macrothink}

Journal of Management Research

ISSN 1941-899X

2012, Vol. 4, No. 4

have been in the business for between 2 to 5 years, while $32 \%$ of them have been in business for 5 to 10 years.

\subsection{Future business plan}

Table 3 shows the future business plans of the women entrepreneurs. Majority of the women entrepreneurs have indicated that as major goals they plan to increase their existing company size and set up another business, but a majority of them did not have any plans regarding acquire other companies and franchising their business. Turan and Kara (2007) have shown that Turkish entrepreneurs have same indication like our research.

Table 3. Future business plan

\begin{tabular}{|l|c|c|}
\hline \multicolumn{1}{|c|}{ Agreement with the future plan } & $\begin{array}{c}\text { Frequency } \\
\boldsymbol{f ( N = 1 9 4 )}\end{array}$ & $\begin{array}{c}\text { Percentage } \\
\text { \% }\end{array}$ \\
\hline Increase the existing company size & 127 & 65.4 \\
Increase employment & 36 & 18.6 \\
Set up other businesses & 96 & 49.5 \\
Start or increase exporting & 12 & 6.2 \\
Acquire other companies & - & - \\
Merge with other companies & 23 & 11.85 \\
Franchise your business & - & - \\
\hline
\end{tabular}

\subsection{Motivation for having own business}

Table 4 shows the major motivating factors for women entrepreneurs in Malaysia. These statements yielded a Cronbach Alpha of 0.821, which is considered reasonable. The data indicate that "greater freedom to adopt their own approach to work" was the most important motivating factor for women entrepreneurs. The entrepreneurs also indicated that they were motivated by "being his/her own boss," "challenging self”, “continue a family tradition,” and "dissatisfaction in the previous job” as other important motivating factors. These results also support the previous research by Turan and Kara (2007). 
Table 4. Motivation for having own business

\begin{tabular}{|l|c|c|}
\hline \multicolumn{1}{|c|}{ Statements* } & $\begin{array}{c}\text { Frequency } \\
\text { f }\end{array}$ & $\begin{array}{c}\text { Percentage } \\
\text { \% }\end{array}$ \\
\hline Wanted greater freedom to adopt my own approach to work & 133 & 68.6 \\
Had been out of work for a period of time & - & - \\
Always wanted to be my own boss & 100 & 51.5 \\
Wanted to make an idea or innovation happen & 31 & 16 \\
Wanted to make more money than was earning before & 76 & 39.2 \\
Wanted to make a lot of money or have a very high income & 50 & 25.8 \\
Wanted to be at forefront of technological ideas & 29 & 14.9 \\
Wanted to develop a hobby or some other activity into a commercial & 17 & 8.8 \\
enterprise & 99 & 51 \\
Wanted to challenge myself & 91 & 46.9 \\
Was dissatisfied in my previous job & 23 & 11.9 \\
Wanted to achieve a better position for myself in society & 48 & 24.7 \\
Wanted to follow the example of someone I admired & 15 & 7.7 \\
Thought I would get more respect working for myself & 89 & 45.9 \\
Wanted to continue a family tradition & 60 & 30.9 \\
Wanted to lead and motivate others & & \\
\hline
\end{tabular}

* Cronbach Alpha 0.821

\subsection{Problems faced}

Table 5 shows the average responses to the statements regarding the challenges faced by the Malaysian entrepreneurs. A reliability analysis on these statements indicated that all these 13 items were measuring the same construct, that is challenges faced (Cronbach's Alpha=0.841). Respondents indicated that "not enough time spent with family," "inability to obtain financial loans", "the stress due to the heavy load of work," "unbalanced family-business life", prejudice against women" and "not enough support" were the most commonly expressed views while "inability to find expert advice for guidance" and "inability to access information resources” problems were not supported. The Irish study used mainly to provide comparisons to our results did not provide quantitative information regarding problems encountered by the women entrepreneurs. However, a qualitative study indicated that "not enough time spent with family," "the stress due to heavy work," and "inability to obtain financial loans" were the major challenges faced (Turan and Kara, 2007). Similarly, Hisrich (1988) reported that financial problems posed a significant problem to Northern Irish entrepreneurs. 
Table 5. Problems faced

\begin{tabular}{|c|c|c|}
\hline Problems faced*a & $\begin{array}{c}\text { Ranked means } \\
\quad(n=194)\end{array}$ & $\begin{array}{c}\text { Std. } \\
\text { Deviation }\end{array}$ \\
\hline Stress due to heavy work & 4.3196 & .68536 \\
\hline Inability to acquire location for the enterprise & 4.2990 & .66403 \\
\hline Inability to spend enough time with family & 4.4227 & .65884 \\
\hline Inability to obtain financial loans for start-up & 4.3505 & .75057 \\
\hline Inability to obtain financing for purchases & 4.4021 & .70208 \\
\hline Unbalanced family-business life & 4.3093 & .52759 \\
\hline Inability to find expert advice for guidance & 2.9588 & 1.02994 \\
\hline Inability to access information resources & 3.4845 & .90270 \\
\hline Not enough support & 4.1134 & .43003 \\
\hline Prejudice against women & 4.1649 & .49330 \\
\hline
\end{tabular}

a A five point scale was used in which 1 indicated "Strongly Disagree" and 5 indicated "Strongly Agree".

\section{Discussion and Conclusion}

Entrepreneurial activity conducted by women has indeed seen a sharp increase over the years. Previous researches by Buttner and Moore, (1999), Lee (1997), Sarri and Trihopoulou (2005) and others are just the tip of the iceberg which attempts to understand even more fully the implications of such a phenomenon. Although other research in the past tends to focus more on the limitations that women entrepreneurs face while conducting their business, it is a good foundation of which the basis of this research lays.

Research has shown that in the past, women rarely ventured into business not because of lack of interest but because of lack of opportunities (Al-Fahal, 2003). As can be seen from the findings of the data collection, a high number of the respondents went into self-employment because they feel that they are not given enough opportunities in their workplace. In addition to that, other factors such as the advent of globalization and technology have ensured that women entrepreneurs now find it easier to venture into the business world on their own. A study done in the United Kingdom concluded that the gap between male and female entrepreneurs in the region was closing. This could be due to the fact that now - more than ever - opportunities are being created all over the world for entrepreneurs to open up businesses. This is backed up by other studies which state that women are estimated to be starting new enterprises at nearly twice the rate of men, and women own approximately 33 per cent of firms with fewer than 500 employees (Matthews and Moser, 1996).

This exploratory study attempts to examine the profile of Malaysian women entrepreneurs. Our findings indicate that a women entrepreneur is about 40 years old. Although this age level might look bit higher compare to other research in this area (Hisrich and Peters 1996). Furthermore, the results regarding a family history of self-employment (having at least one self-employed parent), and being the second child of the family (34\%). However, almost half 
of the women entrepreneurs who participated in the study had less than college education, which is consistent with the previous study (Turan and Kara, 2007). Women entrepreneurs in our study indicated that "having more a network of family and friends that are self-employed" and "relying more on their previous experience" that they establish their new venture” were very important.

Future business plans of entrepreneurs in our sample showed that women entrepreneurs can be characterized as short-time oriented entrepreneurs. They simply lack the strategic orientation and long-term vision, possibly because of having relatively less entrepreneurship education compared to Western entrepreneurs and because of Malaysia's long history of economic instability. These findings indicate that women entrepreneurs are intrinsically and extrinsically (desiring higher income) motivated and highly involved with the control of the operations of their businesses. On the other hand, entrepreneurs report relatively high levels of stress and cope with this stress by working hard.

Finally, the respondents in our sample reported that the major challenges they faced were "greater responsibility," "inability to obtain financial loans for start-up and purchasing," "inability to acquire location for the enterprise," "inability to spend enough time with family," and "stress due to heavy work." These challenges were all consistent with the results of other studies that examined the profile of entrepreneurs (Turan and Kara, 2007; Young and Welsch 1993).

\section{Implication of the Study}

We believe that the findings of this research have revealed some interesting implications for future practitioners and researchers whose aim is to study women entrepreneurs in general. The results show that most of the women entrepreneurs are middle-aged, married and concentrate on the service industry. While it is not fair to generalize these findings as surely women entrepreneurs are not a homogenous group, a clearer understanding of women entrepreneurs is needed. Zapalska, Bugaj, and Rudd (2005) state that this is important in order for future researches to be able to improve the business environment in a way that fosters entrepreneurial growth.

Furthermore, a majority of the respondents were found to be the second-born child in the family. Perhaps a better understanding of women entrepreneurs would be available if the characteristics of women entrepreneurs according to their position in the family were to be assessed. What is required is an understanding of the semantics used by men and women before making assumptions and to explore the influences that these definitional cues have on behavior (Brindley, 2005). While the sum of small parts is important in differentiating different characteristics, it might be a good idea to ascertain the bigger picture in order to get a better view of the topic.

Another implication that can be taken into consideration for future research is the fact that though the respondents valued being independent and being their own boss, they prefer teamwork to working alone. This is an important implication as there are signs that in the future the values that women find important will be in demand. Among them it is the faculty 
of motivating and working in a team (Nielsen and Kjeldsen, 2000). Perhaps what is interesting to note here is that women seem to find themselves capable of performing individually or in a team. While these characteristics are obviously not restricted to women (or women entrepreneurs, for that matter), a study could be done on this as it is certainly a factor that affects success in business.

\section{Limitation of the Study and Future Research}

This study could be suffering from the limitations of sampling bias. We acknowledge the failure to obtain a "truly representative" sample. The entire sample was located in the southern region in Malaysia. Thus, certain businesses may not be represented appropriately in the sample. It is also important to note that it is possible that there might be regionalization of the entrepreneurship, and one needs to be cautious in generalizing the results of this study to the overall population.

Firstly, generally the small sample size might not be substantive enough for this kind of behavioural research. While a majority of these women (63.9\%) do gain profits from their businesses, most of the businesses are small and medium sized and thus, the results of this research cannot be generalized to the entire women entrepreneur community. Thus, while it does not in any way affect the validity of the data, the generalizability of the findings might be skewed towards women entrepreneurs who open small-and-medium sized enterprises as opposed to those who are involved in bigger corporations.

Further research should be directed toward verifying the results of this exploratory study. Future research studies should focus conducting more empirical cross-cultural and/or cross-national studies in different parts of the world and investigate similarities and distinguishing characteristics of the entrepreneurs from various nationalities. Such studies may uncover common characteristics of entrepreneurs and enable researchers to develop more generalizable entrepreneurship theories. Such studies should be based on broader set of cultural values. Similarly, a cross-cultural study investigating differences between entrepreneurs and nonentrepreneurs would provide additional insights.

Finally, due to time and situational constraints, the respondents were only limited to the areas around the states of Malacca and Johor Bahru. A wider scope would have been preferable to ensure that greater generalizability could be tabulated from the scores. However, the response rate was encouraging and this could be the basis of future researches.

\section{References}

Alam, S. S., Fauzi, M. M. J., \& Omar, N. A. (2011). An Empirical Study of Success Factor of Women Entrepreneurs in Southern in Malaysia, International Journal of Economics and Finance, 3(2), 166-175. http://dx.doi.org/10.5539/ijef.v3n2p166

Birley, S., \& Westhead, .P. (1990). Growth and performance contrasts between "types” of small firms. Strategic Management Journal, 11(7), 535-557. http://dx.doi.org/10.1002/smj.4250110705 
Brindley, C. (2005). Barriers to women achieving their entrepreneurial potential: Women and risk. International Journal of Entrepreneurial Behaviour and Research, 11(2), 144-161. http://dx.doi.org/10.1108/13552550510590554

Brown, R. C. (1997). Access to finance for women in business: myths or realities. Keynote address at the International Conference for Women in SMMEs, Stellenbosch, South Africa.

Buttner, H. E., \& Rosen, B. (1992). Perception in the Loan Application Process: Male and Female Entrepreneurs' Perceptions and Subsequent Intentions. Journal of Small Business Management, 30(1), 58-65.

Buttner, E. H., \& Moore, D., P. (1997). Women's Organizational Exodus to Entrepreneurship: Self -Reported Motivations and Correlates with Success. Journal of Small Business Management, 35(1), 34-46.

Chaganti, R. (1986). Management in women-owned enterprises. Journal of Small Business Management, 24(4), 18-29.

Chandralekha, K., Lavoie D., Ferhana K., \& Aparna, I. (1995). Making of rural entrepreneurs - role of support systems. Paper presented at the Internationalising Entrepreneurship Conference in Bunbury, Australia.

Cooper, A. C, Woo, C. Y., \& Dunkelberg, W. C. (1989). Entrepreneurship and the initial size of firms. Journal of Business Venturing, 4(5), 317-332. http://dx.doi.org/10.1016/0883-9026(89)90004-9

Denison, D. \& Alexander, J. (1986). Patterns and Profiles of Entrepreneurs: Data from Entrepreneurship Forums" in Frontiers of Entrepreneurship Research. Ed. Robert Ronstadt, Robert Hornaday, Rein Peterson, and Karl Vesper. Wellesley, Mass.: Babson Center for Entrepreneurial Studies, 578-593.

Dubini, P. (1988). The Influence of Motivations and Environment on Business Startups: Some Hints for Public Policies. Journal of Business Venturing, 4, 11-26. http://dx.doi.org/10.1016/0883-9026(89)90031-1

Emily, T. (2009). Women Hold Up Half the Sky, available at http://www.theedgemalaysia.com/management/146554-entrepreneur-women-hold-up-half-th e-sky.html, dated 17-06-2010.

Erdem, S. (2004). Women entrepreneurs in transition economies: Main obstacles and recommended solutions. Recent Economic Developments and Problems in the Transition Economies, Turkish Manas University Conference in Economics. http://www.manas.kg/pdf/economickonferans/articles/15.pdf, accessed December 9, 2004.

Erwee, R. (1987). Entrepreneurship as a career option for women: an overview of research. South African Journal of Business Management, 18,152-161.

Fernandez, J. P. (1981). Racism and sexism in corporate life. Lexington, Mass. Lexington Books. 
Gundry. L. K., Ben-Yoseph. M., \& Posig. M. (2002). Contemporary Perspectives on Women's Entrepreneurship: A Review and Strategic Recommendations. Journal of Enterprising Culture, 10(1), 67-86. http://dx.doi.org/10.1142/S0218495802000141

Hamilton, D. (1993). Ecological basis for the analysis of gender differences in the predisposition of self-employment, in Klandt, H. 1993. Entrepreneurship and Business Development. Avebary. Aldershot.

Helms. M. (1997.) Women and Entrepreneurship: The Appealing Alternative. Business Perspectives, 10(1), 16-19.

Hisrich, Robert D., \& Brush, Candida, G. (1987). Women entrepreneurs: A longitudinal study. In N. C. Churchill, J. A. Hornaday, B. A. Kirchhoff, O. J. Krasner, K. H. Vesper (Eds.), Frontiers of Entrepreneurial Research (187-199). Boston: MA Babson College.

Hisrich, R. D., \& Öztürk, S. A. (1999). Women entrepreneurs in a developing economy. The Journal of Management Development, 18(2), 114-124. http://dx.doi.org/10.1108/02621719910257639

Hovet, J. (2004). Searching for balance, The Prague Tribune, 103, http://www.prague-tribune.cz/2004/6/7.htm, accessed December 8, 2004.

Isa, M. Z., \& Jusoff, K. (2009). Opportunities to Grab for Malaysian Women Entrepreneuships. Canadian Social Science, 5(5), 35-40.

Larwood, L., \& Gattiker, U. (1989). A Comparison of the Career Paths Used by Successful Men and Women, in Women's Career Development. Ed. Barbara Gutek and Laurie Larwood. Newbury, Park, Calif.: Sage Publications, 129-156.

Lee, J. (1997). The motivation of women entrepreneurs in Singapore. International Journal of Entrepreneurial Behavior \& Research, 3.

Menzies, T. V., Diochon, M., \& Gasse, Y. (2004). Examining venture-related myths concerning women entrepreneurs. Journal of Developmental Entrepreneurship, 9(2), 89-107.

Ministry of Labour Singapore. Women Returning to Work, available at http://www.mom.gov.sg/publish/etc/medialib/mom_library/mrsd/ms.Par.40674.File.tmp/873 _op_02.pdf, dated 17-06-2009

Nguen, Mai. (2005). Women Entrepreneurs: Turning Disadvantages into Advantages, available

http://www.preflightventures.com/resources/WomenEntrepreneursLitSurvey01-2005.htm, retrieved on 17-06-2010

Rozy, H. S. (2009). A briefing on 24 June 2009 at National Association of Women Entrepreneurs of Malaysia, available at: http://www.cedpa.org/images/docs/RozyHayateePresentation.doc, dated 10-05-2010 
Sarri, K., \& Trihopoulou, A. (2005). Female Entrepreneurs' Personal Characteristics and Motivation: A Review of the Greek Situation., Women in Management Review, 20(1), 24-36. http://dx.doi.org/10.1108/09649420510579559

Scheinberg, S., \& Ian C. MacMillan. (1988). An 11 County Study of Motivations to Start a Business, in Frontiers of Entrepreneurship Research. Ed. Bruce Kirchhoff, Wayne Long, W. Ed McMillan, Karl Vesper, and William E. Wetzel. Wellesley, Mass.: Babson College, 669-687.

Schwartz, F. (1989). Management women and the new facts of life. Harvard Business Review, 67(1), 65-76.

Sekeran, U. (2000). Research Methods for Business: A Skill-Building Approach. Third Edition, Joh Wiley \& Sons, Inc.

Shane, S., Lars, K., \& Paul, W. (1991). An Exploratory Examination of the Reasons Leading to New Firm Formation across Country and Gender. Journal of Business Venturing, 6, 431-446. http://dx.doi.org/10.1016/0883-9026(91)90029-D

Shapero, A. (1975). The Displaced Uncomfortable Entrepreneur. Psychology Today (November), 83-88.

Stokes, J. Riger, S., \& Sullivan, M. (1995). Measuring perceptions of the working environment for women in corporate settings. Psychology of Women Quarterly, 19, 533-549. http://dx.doi.org/10.1111/j.1471-6402.1995.tb00091.x

Stoner, C. R., Hartman, R. I., \& Arora, R. (1990). Workhome role conflict in female owners of small businesses: an exploratory study. Journal of Small Business Management, 28(1), 30-38.

Teoh, W.M.Y., \& Chong, S.C. (2008). Improving Women Entrepreneurs in Small and Medium Enterprises in Malaysia: Policy Recommendations. Communications of the IBIMA, 2, 31-38.

Turan, M., \& Kara, A. (2007). An exploratory study of characteristics and attributes of Turkish entrepreneurs: A cross-country comparison to Irish entrepreneurs. Journal of International Entrepreneurship, 5, 25-46. http://dx.doi.org/10.1007/s10843-007-0014-2

Winn, J. (2004). Entrepreneurship: Not an easy path to top management for women. Women in Management Review, 19(3), 143-153. http://dx.doi.org/10.1108/09649420410529852

Winn, J. (2005). Women Entrepreneurs: CanWe Remove the Barriers? International Entrepreneurship and Management Journal, 1, 381-397. http://dx.doi.org/10.1007/s11365-005-2602-8

Zikmund, W.G. (2000). Exploring Marketing Research, $7^{\text {th }}$ Edition, Dryden Press, Fort Worth. 